\title{
Azərbaycan Xalq Cümhuriyyəti: “AZӘRTAC”'n yaranma zərurəti və keçdiyi yol
}

\author{
The Heritage Of Azerbaijan People's Republic-Azertac: Necessity For The Establishment \\ and The Challenges It Passed Through
}

\author{
Namiq Ohmədov a* \\ ${ }^{a}$ Bakı Dövlət Universiteti Jurnalistika fakültəsi, Beynəlxalq Jurnalistika kafedrasının doktorantı, Bakı/Azərbaycan \\ ORCID: 0000-0003-1970-182X
}

\section{MAKALE BİLGISI}

Makale Geçmişi:

Başvuru tarihi: 2 Ekim 2018

Düzeltme tarihi: 4 Ocak 2019

Kabul tarihi: 23 Ocak 2019

Açar sözlor:

Azərbaycan Xalq Cümhuriyyəti

AzərTAc, Sovet Dövrü

SITA

Informasiya

MAKALE BILGİSI

\section{Makale Geçmişi:}

Başvuru tarihi: 2 Ekim 2018

Düzeltme tarihi: 4 Ocak 2019

Kabul tarihi: 23 Ocak 2019

Anahtar Kelimeler:

Azerbaycan Halk Cumhuriyeti

AzerTAc

Sovyet Dönemi

Bilgi

\section{ART ICLE INFO}

\section{Article history:}

Received 2 October 2018

Received in revised form 4 January 2019

Accepted 23 January 2019

Keywords:

Azerbaijan People's Republic

AzerTAc

the Soviet-era

TASS

Information

\section{XÜLASə}

Azərbaycan Xalq Cümhuriyyətinin yadigarı və Şərqdə ilk xəbər agentliklərindən olan AzərTAc-1n keçdiyi çətin və şərəfli yol məqalənin mövzusudur. Agentliyin formalaşması dövrünü 3 mərhələyə bölmək olar. Birinci mərhələ1920-ci ilin mart-aprel aylarını əhatə edir. Milli xəbər agentliyi ilk xəbərlərini bu dövrdə yaymağa başlamıșdır. İkinci mərhələ vaxt baxımından xeyli uzun bir dövrü - sovet dövrünü əhatə edir. On nəhayət, üçüncü mərhələ ikinci müstəqilliyimizi qazandığımız dövrü əhatə edir. Bu dövrdə - 1992-ci ildə AzərTAc tarixi adını bərpa etmiş, amma müstəqilliyin ilk illəri onun üçün çox çətin olmuş, agentliyin birdən-birə təsərrüfat hesabına keçirilməsi ciddi iqtisadi çətinliklərə səbəb olmuşdur. 1993-cü ildə Heydər Oliyevin Azərbaycanda siyasi hakimiyyətə qayıdışı AzərTAc-ın da fəaliyyətində yeni inkişaf mərhələsi olmuşdur.

ÖZ

Makalenin konusu Azerbaycan Halk Cumhuriyeti'nin yadigarı ve Doğu'da ilk haber ajanslarından biri olan AzerTAc'ın geçtiği zor, ama şerefli yoldur. Ajansın oluşum dönemini 3 aşamaya ayırabiliriz. Birinci aşama 1920 senesinin Mart-Nisan aylarını kapsıyor. Milli haber ajansı ilk haberlerini bu dönemde yayınlamaya başlamıştır. İkinci aşama zamansal açıdan uzun dönemi kapsıyor - tüm Sovyet Dönemi’ni. Üçüncü aşamaysa ikinci özgürlüğümüze kavuştuğumuz dönemi kapsıyor. Bu dönemde - 1992 senesinde AzerTAc tarihi ismine geri dönmüştür. Ama özgürlüğün ilk yılları onun için çok zor olmuş, ajans birden bire kendi bütçesinden yönetilmeye başlayınca, ciddi ekonomik sorunlar çıkmıştır. 1993 senesinde Haydar Aliyev'in Azerbaycan'da siyasi hakimiyete dönüşü AzerTAc'ın faaliyetinde yeni gelişme çağı olmuştur.

* Sorumlu yazar/Corresponding author

e-posta: tuqay59@mail.ru 


\section{Giriş: Azərbaycan Xalq Cümhuriyyətinin mətbuat və informasiya siyasəti haqqunda}

Türk-İslam dünyasında ilk demokratik, hüquqi və dünyəvi dövlət olan Azərbaycan Xalq Cümhuriyyətinin (AXC) mustəqilliyini elan etməsi xalqimiz ucun taleyüklü bir uğur idi. 1918-ci il mayın 28-də demokratik və ümumbəşəri dəyərlərə söykənən ilk respublika - AXC-nin çəmi 23 aylıq tarixi olsa da, onun yaratdığı milli istiqlal ideyaları azərbaycançılıq tariximizin ən şərəfli səhifələrindən oldu. AXC az bir vaxtda parlamenti, hökuməti, ordusu, gömrük və hüquq mühafizə orqanları olan, dövlət rəmzlərinə malik, vətəndaş hüquqlarını hər şeydən uca tutan demokratik, dünyəvi və unitar dövlətə çevrildi. Amalı millət yolu, haqq yolu olan AXC yarandığı ilk gündən "türkləşmək, islamlaşmaq, müasirləşmək" şüarını rəhbər tutaraq cəmiyyətin bütün sahələrində süqutunun son gününə kimi apardığı islahatları davam etdirmişdir. Siyasətçilərin də qeyd etdiyi kimi “...Qafqaz regionunda maraqların kəskin şəkildə toqquşduğu dramatik tarixi zamanda Azərbaycanda cümhuriyyət yaranmasayd, sonradan ölkəmizin müttəfiq respublika kimi Sovet İttifaqının tərkibinə daxil olması və bu İttifaq da dağılarkən, bir suveren dövlət kimi öz müstəqilliyini bərpa etməsi də mümkün olmayacaqdı" (Feyziyev, 2011).

Azərbaycan Xalq Cümhuriyyətinin 23 ay ərzində qəbul etdiyi qərarların hər birinin kökündə demokratiyanın bərqərar olunması, milli ruhun yüksəldilməsi dayanırdı. Q1sa müddət ərzində dövlət atributlarının, dövlət və hərbi quruculuq, iqtisadiyyat və mədəniyyət, təhsil və səhiyyə sahələrində qanun və qərarların qəbul edilməsi tarixi reallıqlar idi. AXC mətbuat və nəşriyyat işinin yenidən qurulması üçün də tarixi qərarlar qəbul etdi. Mətbuat və söz azadlığının təmin edilməsi Cümhüriyyətin demokratik dəyərlərə verdiyi önəmin təzahüri idi. "Azərbaycan mətbuatı tarixində 1918-20 illər, bütün əvvəlki dövrlərə nisbətən, ən yüksək inkişaf mərhələsidir. Bu dövrün mətbuatı həm keyfiyyət, həm də kəmiyyət baxımından, milli mədəniyyətin mühüm tərkib hissəsi kimi, Azərbaycan həyatının canlı salnaməsinə çevrildi. 1918-ci il iyulun 3-də Azərbaycan Cümhuriyyəti hökuməti «Azərbaycan Cümhuriyyəti hökumətinin xəbərləri»nin nəşri haqqında qərar qəbul etdi. Həftədə iki dəfə nəşr olunan hökumət xəbərlərində əsasən rəsmi qərarlar, əmrlər, təlimatlar dərc edilirdi. İki il içərisində ölkədə 100-ə yaxın adda qəzet və jurnal çıxmışdır" (Azərbaycan Xalq Cümhuriyyəti Ensiklopediyası, 73).

"AXC-nin mətbuat və informasiya sahəsində atdığı daha uğurlu bir addım Azərbaycan Dövlət Teleqraf Agentliyi, qisaca olaraq "AzərTAc"-ın yaradılması ilə bağlıdır" (Aslanov, A., Musayev, V., @ İsmayılov, D., 2008, 15). Azərbaycan Xalq Cümhuriyyəti dövründə yaradılmış AzərTAc Şərqdə ilk xəbər agentliklərindən olmuşdur. Cümhuriyyət dövründə AzərTAc-1n yaradılması dövlətin siyasi və ideoloji dəstəyi gücləndirmək, real və dürüst informasiyalar vasitəsi ilə ideoloji təminat almaq, həm də cəmiyyəti operativ və doğru xəbərlərlə təhciz etmək istəyindən bəhrələnirdi. Öz növbəsində bunu siyasi və ictimai tələblərə əsaslanan tarixi şərait də təsdiq etməkdə idi. Digər tərəfdən, dünyanın idarəetmə sisteminə də diqqət edəndə informasiyanın hakim rolunu görməmək mümkün deyildi. Hətta keçmiş imperiyalar belə monopoliya siyasətini həyata keçirməkdə yalnız siyasi təzyiq vasitələrindən deyi, həm də ideoloji təsir vasitələrindən də bəhrələnməyə çalışdıqları təsdiqini tapır."20-ci əsrin əvvəllərində dünyada kedən proseslərə diqqət edəndə demokratik inqilabi hərəkatların gücləndiyinin, milli azadlıq uğrunda mübarizədə söz, mətbuat və informasiya azadlıqlarının öndə dayandığı diqqəti cəlb edir. Buna görə də milli azadlıq uğrunda mübarizələrin qızışdığı bir zamanda informasiya işinin çox vacib bir faktora çevirilməsi artıq zamanın tələbi idi” (Ohmədov, 2018b).

Belə bir zaman kəsiyində yaradılmasının zəruriliyi gündəmə gələn AzərTAc-1n (indi AZORTAC) keçdiyi çətin və eyni zamanda şərəfli yolun öyrənilməsində 3 mərhələ diqqəti cəlb edir. Birinci mərlələ vaxt baxımından olduqca kiçikdir, hətta Cümhuruyyətin fəaliyyət dövründən də 10 dəfə kiçikdir: 1920ci ilin mart-aprel aylarını əhatə edir. Bu əsasən təşkilatı işlərin aparılması və fəaliyyətə başlanması dövrüdür. İkinci mərhələ vaxt baxımında xeyli uzun bir dövrü əhatə etməklə agentliyin sovet dövrü fəaliyyətini və ən nahəyət üçüncü mərhələ ikinci müstəqilliyimizi qazandığımız dövrü əhatə edir.

\section{Azərbaycan Teleqraf Agentliyinin (AzərTAc) təşkili}

Müsəlman Şərqində ilk olaraq Cümhuriyyətin qurulduğunu elan etmiş demokratik bir quruluş informasiya məkanının yaradılmasına da biganə qala bilməzdi. Azərbaycan Teleqraf Agentliyinin təşkil edilməsində əsas məqsəd dünyaya inteqrasiya, o cümlədən Avropa, Asiya və Amerikadan alınan məlumatlarla Xalq Cümhuriyyətinin dövlət qurumlarını, eyni zamanda yeni dövlətin informasiya siyasətini cəmiyyətə çatdıran mətbuat orqanlarını, ictimai təşkilatları təmin etmək idi. Digər tərəfdən "Azərbaycan reallıqlarının, ölkənin ictimai-siyasi həyat1, hərbi quruculuq işləri, iqtisadi uğurlar, hökümətin və parlamentin fəaliyyəti haqqında məlumatların yayılması da önəmli məsələlərdən idi" (Ohmədov, 2018a). Bu məlumatların təkcə bölgələrə yox, eyni zamanda qonşu ölkələrə, Qafqaz və Avropa ölkələrinə də göndərilməsi vacib idi. Agentliyin fəaliyyət layihəsində, məlumatlar əsasında gündəlik "Bülletenlər", ən vacib informasiyalar əsasında isə "Xəbərlər" hazırlamalı və sərəncamında olan vasitələrdən istifadə etməklə onları yaymalı idi.

Oslində bu reallıqları anlayan hökumət hələ 1919-cu il martın 3-də Nazirlər Şurasının iclasında Azərbaycan Teleqraf Agentliyinin təşkili edilməsi məsələsini gündəliyə salmış və müzakirə olunmuşdu. İclasda Nazirlər Şurasının sədri Fətəli xan Xoyskinin bu məsələnin vacibliyini açıqlayan məruzəsi dinlənilmiş, hətta o vaxtlar Xalq Maarif naziri olan Nəsib bəy Usubbəyli Azərbaycan Teleqraf Agentliyinin təşkil edilməsi haqqında rəsmi tapşırıq da almışdı. Amma ilk gündən ortaya cıxan texniki cətinliklər, daha doğrusu agentliyinin real fəaliyyətinin, informasiyanın qəbulu və ötürülməsinin bilavasitə radio - texniki vasitələrdən asılı olduğundan bu qərar dəyişdirilmiş, agentliyin təşkil olunması məsələsi Xalq Maarif Nazirliyindən alınaraq Poçt və Teleqraf Nazirliyinn sərəncamına verilmişdi.

Agentliyin Osasnaməsində 1920-ci il yanvarın 1-də onun Poçt və Teleqraf Nazirliyinin nəzdində xüsusi bölmə hüququnda fəaliyyəti bildirilirdi (ARDA, Azərbaycan Respublikası Dövlət Arxivi, f.51). Azərbaycan Teleqraf Agentliyinin baş redaktor vəzifəsini tutan şəxs agentliyin rəhbəri olaraq təqdim edilirdi. İşin təşkili ilə əlaqədar nizam-intizam qaydalarını həll etmək, layihələri, smetanı hazırlamaq üçün baş redaktorun rəhbərliyi altında Şura yaradılmalı idi. Agentliyin rəhbəri olan baş redaktor Poçt və Teleqraf Nazirliyi tərəfindən təyin olunurdu. Oməkdaşların işə qəbulu və işdən azad edilməsi isə 
baş redaktor tərəfindən müəyyənləşdirilirdi. Agentliyin buraxdığı bülletenlərə abunə yazılışı onun gəlirlərini müəyyənləşdirir və gəlirlər bu mənbələr əsasında formalaşdırılırdı.

Azərbaycan Teleqraf Ajanslığının -AzərTAc-ın ştatlarının layihəsi və əsasnaməsi 1920-ci il fevralın 2-də hökümətin iclasında müzakirə edilir və müəyyən dəyişikliklərlə parlamentə çıxarılması qərara alınır. Bundan təxminən 20 gün sonra-- fevralın 23-də parlamentin iclasında "Bak1 sahil radiostansiyanın ştatı haqqında" qanun layihəsi müzakirəyə çıxarılır. Müzakirələr ciddi bir siyasi fəallıqla keçir və deputatlar Azərbaycan Teleqraf Agentliyinin yaradılmasını təzəcə müstəqilliyini qazanmış ölkə üçün olduqca zəruri olduğunu qeyd etməklə, belə bir agentliyin informasiya mübadiləsində əvəzsiz əhəmiyyətini xüsusi vurğulamışlar. Məruzəçi kimi çıxış edən deputat Ağa Eminov sahil radiostansiyanın (simsiz teleqraf) ikisi qəbuledici, biri isə həm qəbuledici, həm də ötürücü olmaqla üç aparatdan ibarət olduğunu bildirmişdi. Aparatların sutkada 70 minə qədər söz qəbul edə biləcəyini bildirən məruzəci hökumətin teleqraf agentliyi yaratmaq qərarını və bu barədə hazırlanmış layihəni parlamentə təqdim etmişdir.

Parlament müzakirəsində çıxış edən deputat Aga Aşurov teleqraf agentliyin yaradılması haqqında hökumət layihəsinin dəstəklənməsini parlamentdən xahiş etmiş və fikirlərini əsaslandıraraq demişdir: "Teleqraf agentliyimizin yoxluğundandır ki, düşmənlərimiz haqqımızda və Bakı xüsusunda çürbəcür yalan və həqiqətdənkənar şaiyələr və xəbərlər nəşr edirlər. Әgər bizim agentliyimiz olsa idi, o zaman biz onun vasitəsi ilə haqqımızda nəşr olunan xəbərləri də bilərdik və lazım olan cavabları da verərdik" (Ohmədov, 2018a). Təbii ki, bu yencə qurulmuş dövlətin informasiya siyasətinə verdiyi önəmin vacibliyini təsdiq edən və dəyərləndirən önəmli fakt idi. Beləliklə, çox operativ bir şəkildə, bu müzakirələrdən bir həftə sonra Azərbaycan Teleqraf Ajanslığ 1 -AzərTAc fəaliyyətə başladı.

\section{AzərTAc-In fəaliyyətinin Cümhuriyyət dövrü}

Cümhuriyyətin rəsmi qəzeti olan “Azərbaycan” qəzeti 1920ci il martın 2-də ilk dəfə olaraq “AzərTAc" imzası ilə xəbərlər yayd1 ("Azərbaycan" qəzeti 1920, 2 mart). Bu agentliyin yaradılması haqqında olan bəzi mülahizələri təkzib edən və AzərTAc xəbər agentliyin 1920-ci il martın 1-də fəaliyyətə başladığını ortaya qoyan və təsdiq edən önəmli fakt sayıla bilər. Qəzetin 3 mart tarixli nömrəsində də Şuşa, Qaryağın (Füzuli) və Xankəndidən alınmış qısa xəbərlər “AzərTAc-1n daxili xəbərləri"( "Azərbaycan” qəzeti, 1920, 3 mart) ad1 altında dərc edilmişdi. Yenə "Azərbaycan" qəzeti martın 9-da "Gürcüstana yardım" sərlövhəli xəbər dərc edir. Bu AzərTAc1n 7 mart tarixli 7 nömrəli bülletenindən götürülmüş xəbər idi. Gürcüstana yardım barədə xəbər təkcə siyasi tərəfdən yox, həm də o qədər də böyük maddi imkanlara malik olmayan gənc Azərbaycan hökümətinin qonşulara və milliyyətindən asılı olmayaraq insanlığa olan humanist münasibətinin göstəricisi idi. Xəbərdə deyilir ki, Nazirlər Şurası zəlzələdən zərər çəkmiş Gürcüstan əhalisinə maddi yardım göstərmək üçün Maliyyə Nazirliyinə Gürcüstan hökümətinə 2 milyon rubl ayrılması barədə qanun layihəsi hazırlamağı və parlamentin təsdiqinə verməyi tapşırmışdır ("Azərbaycan" qəzeti, 1920, 9 mart)
Bu tarixdən az sonra, 1920-ci il martın 25-də Azərbaycan Teleqraf Agentliyinin Xalq Maarif Nazirliyinə göndərdiyi 17 nömrəli məktub-bildirişində (təliqə) Azərbaycan Teleqraf Agentliyinin hökümətin 1 mart tarixli qərarına uyğun olaraq Poçt və Teleqraf Nazirliyinin nəzdində yaradıldığı və martın 1-də fəaliyyətə başladığı təsdiq olunur, eyni zamanda agentlikdə formalaşma dövrü olduğu diqqətə çatdırılır. Burda diqqət cəlb edən bir məlumat da var: agentliyin aprel ayının 1dən AzərTAc-ın bülletenlərinə abunə yazılışına başlanıldığı haqqında da məlumat yer alır. Abunə xərcləri çatdırılma da daxil olmaqla Bakıda 300 rubl, Azərbaycanın başqa şəhərlərində isə 3000 rubl məbləğində müəyyənləşdirildiyi məlum olur. Məktub-bildirişdə agentliyin müvəqqəti olaraq Poçt və Teleqraf Nazirliyinin Naberejnaya və Sadovaya küçələrinin kəsişməsindəki binasında yerləşdiyi haqqında da molumat var (Aslanov,2011, s.56).

AzərTAc-1n xəbər bülletenləri hər gün nəşr edilirdi. Hətta bayram günləri də çıxan bületenlər iki dildə- Azərbaycan və rus dillərində buraxılırdı. Xəbər büllütünlərində dərc edilən materiallar yeni həyata vəsiqə almış Azərbaycan dövlətinin içtimai-siyasi həyatında baş verən mühüm hadisələrin işıqlandırılmasından, hökümətin gördüyü işlərin mahiyyət və xronikasından ibarət olan məlumatların abunəçilərə çatdırılmasından ibarət idi. Bülletenlərdə xarici ölkələrdən alınmış operativ xəbərlər də dərc olunurdu. Moskva, Paris, Bəsrə, Roma, Tiflis, Daşkənd, Şimali Qafqaz, Zakaspi, Qara dəniz sahilləri radiostansiyalarından, eləcə də telefon və teleqrafla müxbirlərdən alınmış xəbərlər həm əhatə dairəsinə görə, həm də dəqiqliyinə və məlumat zənginliyinə görə abunəcilərin maraqlarını doğruldurdu.Agentliyin texniki imkanları əslində o qədər də zəngin olmasa da, dövrün tələblərinə cavab vermək baxımından qənaətbaxış hesab edilə bilərdi: həm "sönən", həm də "sönməyən" rəqs tipli stansiyalarla işləyən bu avadanlıqlar məlumatların alınıbverilməsində öhdələrinə düşən vəzifələrin yerinə yetirilməsi və ilkin olaraq hər iki radiostansiyadan göndərilən xəbərləri qəbul etməyi imkan verirdi.

Digər mənbə və strukturların imkanlarını nəzərə almasaq, agentlik təkcə radiostansiyaların fəaliyyəti sayəsində sutka ərzində 40 min işarəyə qədər ən müxtəlif miqyaslı xəbərləri qəbul edə bilirdi (Aslanov, 2008, s.76). Xəbər agentliyinin bu imkanları onun gələcək fəaliyyətinin daha geniş, daha əhatəli və uğurlu olacağını təsdiqləyirdi. Belə ki, yaxın vaxtlarda başqa ölkələrin informasiya agentlikləri ilə əlaqələrin qurulmas1 və ikitərəfli müqavilələr bağlanması yaxın dövrün planlarından idi. $\mathrm{Bu}$ agentliyin öz xəbərlərini əvvəlcə yaxın olan qonşu ölkələrə, daha sonra uzaq ölkələrə yayması üçün imkanlar yaradacaqdi.

Azərbaycanın bölgələrinə isə xəbərlər əyalət mərkəzində quraşdırılması planlaşdırılan radiostansiyalar vasitəsi ilə verilməsi nəzərdə tutulurdu. Eyni zamanda yeni yaradılmış hərbi nazirliyin tabeliyində olan stansiyalardan da bu məqsədlə istifadəsinə içazə verilirdi. Xəbərlərin telefon və teleqraf vasitəsilə ötürülməsi də gündəmdə idi. Amma təəssüflər olsun ki, bolşevik Rusiyasının işğalı nəticəsində “1920-ci il aprelin 28-də Azərbaycan Xalq Cümhuriyyəti süqut etdi və onun təsis etdiyi AzərTAc da cəmi iki aya yaxın bir müddətdə müstəqil fəaliyyət göstərə bildi. Elə həmin gün Rusiya Teleqraf Agentliyi -ROSTA bolşevik təbliğatına xas olan xüsusi bir "siyasi hiyləgərliklə" Bakıda çevriliş olduğunu 
və xalq kütlələrinin Azərbaycan Cümhuriyyətini devirdikləri barədə xəbərləri bütün dünyaya yaydı" (Aslanov, 2008, s. 38).

\section{Sovet dövrü: AzərTAc, ZaqTA, AzərTA, Azorinform vo ROSTA, QafROSTA, SITA}

Azərbaycanda sovet hakimiyyətinin qurulduğu ilk aylarda o qədər də geniş imkanların verilmədiyi AzərTAc formal olaraq müstəqilliyini qoruyub saxladı, amma onda da agentlik əslində Rusiya Teleqraf Agentliyinin (ROSTA) filialı kimi fəaliyyət göstərirdi. Bölgələrdən göndərilən xəbərlər istisna olmaqla, AzərTAc bütün xəbərləri ROSTA-dan alırdı. Bu informasiyalar arasında Moskva, Petroqrad, Çelyabinsk, Saratov və Vladivostokdan alınan, habelə Rusiyanı bürüyən vətəndaş müharibəsi haqqında xəbərlər geniş yer tuturdu. Yeri gəlmişkən qeyd edim ki, bu prinsip Sovet rejiminin bütün dövrlərində özünü göstərmiş, hətta SITTA-nın fəaliyyəti dövründə belə xaricdən verilən bütün xəbərlər yerli xəbər agentliklərinə ancaq Moskvadan daxil olmuşdur. Müttəfiq respublikaların xəbər aşentlikləri isə onları rus dilində və ən yaxşı halda əlavə olaraq yerli xalqların dillərinə tərcümə edib yaymaq olmuşdur.

O vaxtlar da AzərTAc-ın ROSTA-dan aldığı xəbərlərin məramı bolşevik hakimiyyətinin irtica siyasətinə "sulhpərvərlik və ədalət donu" geyindirmək olmuşdu. Mahiyyət və məzmunca təbliğat və təşviqat xarakteri daşıyan bu xəbərlər divar qəzetlərinə, plakat vərəqələrinə və yerli qəzetlərə göndərilirdi. 1920-ci il iyunun 9-da AzərTAc xəbər agentliyi ROSTA-nın bir bölməsi olur. Bu Nəriman Nərimanovun "Azərbaycan Mərkəzi Mətbuat Kollegiyas1 yaradılması haqqinda" dekreti imzalanmasından sonraya təsadüf edir. Həmin dekretlə o vaxt fəaliyyət göstərən ROSTA-nın Qafqaz diyar şöbəsinin Azərbaycan bölməsi (AzQafROSTA) aparıcı şöbələrdən biri kimi Kollegiyaya daxil edilir. Quruma ROSTA-nın Qafqaz üzrə səlahiyyətli nümayəndəsi, kommunist S.Y.Boqdatyev rəhbərlik edirdi. Tanınmış jurnalist Ağababa Yusifzadə o vaxtlar informasiya işinin təşkili üzrə kollegiyanın sədri olmuşdu.

1920-ci il avqustun 20-də Xalq Maarif Nazirliyinin kollegiya iclasında AzərTAc-ın vəziyyəti və prespektivi müzakirə olunmuş, AzərTAc-ın hələ formalaşma mərhələsi yaşadığından qarşısında qoyulan bütün tapşırıqları yerinə yetirmək iqtidarında olmadığını bildirilmişdi. Təklif edilmişdir ki, əgər bölgələrdə və bəzi Şərq ölkələrində agentliyin müxbir məntəqələri açılsa və əməkdaşların maddi vəziyyəti yaxşılaşdırılsa, agentlik daha məhsuldar və faydalı fəaliyyəti ilə özünü təsdiq edə bilər. Amma kollegiya iclasının sədri olan D. Bünyadzadə bu təklifə qarşı çıxmaqla, AzərTAcın maddi-texniki bazasının möhkəmləndirilməsinə, o cümlədən bunun üçün yeni avadanlıqların alınmasına heç bir ehtiyac görmədiyini bildirmişdi. Hətta ən mühüm və vacib xəbərlərin təhcizatçısı ROSTA olduğundan, buna gərək olmadığını söyləmişdir. Digər iclas iştrakçılarının da bu fikirə dəstək olması ilə müzakirə bitmiş və "respublikanın gücünə və vəsaitlərinə uyğun olaraq, AzərTAc-1n gələcək mövcudluğu"nun müəyyənləşməsi ilə məsələ həllini tapmışdı. Eyni zamanda AzərTAc-ın yeni varisi AzQafROSTA-nın fəaliyyəti təkcə Bakı ilə məhdudlaşmamış, respublikanın digər şəhərlərində də (Gəncə, Şuşa, Lənkəran və s.) onun bölmə və məntəqələri fəaliyyət göstərirmişdi. Onlar yerlərdə baş verən hadisələr haqqinda məlumatlar hazırlayır və daxili imkanlarından istifadə etməklə informasiya xarakterli divar qəzetləri və təşviqat plakatları da buraxırdılar (Şərifov, 2008, 11).

1921-ci ildə agentlik QafRosta-nın bazasında yenidən təşkil olundu. Həmin ilin avqustunda adı dəyişdirilərək AzərTA adlandırıldı. AzərTA QafROSTA-nın bazasında yenidən təşkil olunandan sonra Qubad Qasımov iyulun 14-də agentliyin direktoru təyin edilir. "Azərbaycan musiqi mədəniyyəti tarixinin, o cümlədən Üzeyir Hacıbəyovun yaradıcılığını" məşhur araşdırıcılarından biri kimi tanınmış Qubad Qasımov xatirələrində bu barədə yazırdı; "1921-ci ildə məni yəni informasiya orqanının direktoru təyin etdilər. $\mathrm{O}$ vaxt mən hərbi hissələrdən birində döyüşçülər arasında savadsızlığın ləğvi üzrə fövqəladə komissiyaya başçılıq edirdim. Siyasi və mədəni iş sahəsində müəyyən səriştəm olsa da, jurnalist təcrübəm yox idi. O vaxt gənc Azərbaycan Sovet Respublikasında kadrlar problemi ən kəskin məsələlərdən biri idi və belə gözlənilməz təyinatlar adi hal sayılırdı" (Aslanov, 2005, 10).

1922-ci ildə SSRİ qurulduqdan sonra isə AzərTA Sovet İttifaq1 Teleqraf Agentliyinin (SITA) filialı kimi fəaliyyət göstərməyə başladı. Bir müddət sonra, 1923-cü ilin martında Zaqafqaziya Federasiyası yaradıldı və üç Cənubi Qafqaz respublikasının informasiya agentlikləri ZaqTA adı altında birləşdirildi. 1936-c1 ildə isə AzərTA yenidən müstəqil informasiya vasitəsi kimi fəaliyyətini bərpa etdi.

\section{Milli xəbər agentliyi yeni mərhədə}

1969-cu ildə ulu öndər Heydər Oliyev Azərbaycanda siyasi rəhbərliyə gəldikdən sonra respublika həyatının bütün sahələrində olduğu kimi o vaxt Azərinform adlanan milli xəbər agentliyi də öz inkişafının yeni mərhələsinə qədəm qoydu. 1970-ci ildə SİTA Moskvadakı baş ofisini ilk dəfə tam kompüterləşdirməyə başlayanda Heydər Oliyevin səyləri nəticəsində ittifaq respublikaları arasında Ukrinformdan sonra Azərinform da o dövrün müasir "Videoton", daha sonra isə "Olivetti" markalı kompüterləri ilə təchiz edildi. "Ümummilli lider Heydər Oliyev respublikaya rəhbərliyinin hər iki dövründə ölkə həyatının bütün başqa sahələri kimi, mətbuata da daim böyük diqqət və qayğı göstərmişdir. Məhz onun sayəsində hələ sovet dövründə agentliyin ittifaqda birincilər sırasında, o vaxtın on müasir texniki avadanlığı ilə təchiz edilməsi, müstəqillik illərində AZӘRTAC-1n rəsmi informasiya orqanı statusunun bərpa olunması, fəaliyyətinin təkmilləşdirilməsi vo maddi-texniki bazasının möhkəmləndirilməsi xüsusi önəm daşımışdır" (Aslanov,2005, 67)

Sovet hakimiyyəti dövründə 8 dəfə ad dəyişikliyinə məruz qalan agentliyin tarixi adı Azərbaycan dövlət müstəqilliyini bərpa etdikdən sonra qaytarıldı. 1992-ci ildə AzərTAc tarixi adını bərpa etsə də, müstəqilliyin ilk illərində ciidi çətinliklərlə üzləşmiş, hətta ciidi gərginliklərin yaşandığ olduqca ağır bir zamanda agentliyin təsərrüfat hesabına keçirilməsi ciddi iqtisadi çətinliklər yaratmışdır. 1993-cü ildə Heydər Oliyevin Azərbaycanda siyasi hakimiyyətə qayıdışı AzərTAc-ın da fəaliyyəti üçün geniş imkanlar açmışdır. Azərbaycan Prezidentinin imzaladığı fərman və sərəncamlarla agentlik dövlət himayəsinə götürülmüş, fəaliyyətinin təkmilləşdirilməsi, maddi-texniki bazasının möhkəmləndirilməsi və yaxşılaşdırılması üçün olduqca ciddi tədbirlər görülmüşdür. AzərTAc bu dövrdə tarixində olmayan bir ilkə də imza atmışdır: xarici ölkələrdə müxbir məntəqələri 
açılmışdır (Aslanov, A., Musayev, V., @İsmayılov, D., 2008, 134).

Ümummilli lider Heydər Oliyevin siyasi hakimiyyətə qayıdışından sonra Azərbaycan Respublikasının dünya birliyində öz yerini tutması, ulu öndərin daxili və xarici siyasətinin müasir mərhələdə Prezident İlham Oliyev tərəfindən uğurla davam etdirilməsi sayəsində ölkənin regionda şəksiz lider dövlətə çevrilməsi, beynəlxalq aləmdə nüfuzunun daha da artması və mövqelərinin möhkəmlənməsi, habelə AzərTAc-1n madditexniki bazasının gücləndirilməsi, fəaliyyətinin təkmilləşdirilməsi sahəsində dövlət səviyyəsində görülən ardıcıl tədbirlər agentliyin xarici əlaqələrinin inkişafinda, onun dünya informasiya məkanına çıxmasında həlledici rol oynamışdır (Aslanov, 2005, 30). Mətbuat tədqiqatçıları da agentliyin fəaliyyətini yüksək dəyərləndirmiş, xüsusən də milli dildə informasiya siyasətini formalaşmasında onun xidmətlərinə xüsusi önəm vermişlər. "AzərTAc çox çətin və şərəfli yol keçib. Bütün maneələrə baxmayaraq, hətta keçmiş sovet məkanında da AzərTAc öz xəbərləri ilə tanınır. Agentlik Azərbaycan haqqında xəbərləri ölkənin sərhədlərindən kənara çıxara bilib. Bütövlükdə Azərbaycan dilində informasiyanın formalaşmasında vo ölkəmizin informasiya siyasətinin müəyyənləşdirilməsində agentlik əvəzsiz rol oynayı"

(Enserov, 2009, s.5).

AzərTAc-1n beynəlxalq əlaqələrinin qurulması və formalaşması da Azərbaycanın dövlət müstəqilliyinin bərpasından sonrakı illərə təsadüf edir. "Müstəqil dövlətin rəsmi xəbər agentliyinin dünya informasiya məkanına çıxmasına nail olmaq, xarici tərəfdaşlarla sıx əlaqələr qurmaq, Ermənistan Respublikasının Rusiya Federasiyasının hərbisiyasi dairələrinə arxalanaraq hərbi təcavüzü ilə üzləşmiş, məkrli erməni təbliğat maşınının və xaricdəki güclü erməni lobbisinin məqsədyönlü antiazərbaycan fəaliyyəti nəticəsində informasiya blokadasına düşmüş Azərbaycan Respublikasının haqq işini, ölkəmiz

haqqinda həqiqətləri dünyaya bəyan etmək AzərTAc-1n səmərəli xarici əlaqələr qurmasını həyati vacib məsələyə çevirmişdi. Lakin bu, yalnız AzərTAc-1n səyləri sayəsində mümkün deyildi, bütövlükdə müstəqil dövlət kimi Azərbaycan Respublikasının özünü dünyada tanıtması ilə bilavasitə bağlı idi” (Aslanov, 2010, 182).

1995-ci il martın 3-dən Nazirlər Kabineti yanında Dövlət Teleqraf Agentliyi (Azərinform-Azərtac), 2000-ci il yanvarın 17-dən isə Azərbaycan Dövlət Teleqraf Agentliyi (AzərTAc) adlandırılmağa başladı. Nəhayət, Prezident İlham Oliyevin 2015-ci il 26 fevral tarixli Sərəncamı ilə Azərbaycan Dövlət İnformasiya Agentliyi (AZORTAC) adlandırıldı.

AZORTAC-ın qlobal informasiya məkanında daha geniş təmsil olunması, Azərbaycan haqqinda obyektiv informasiyanın yayılma coğrafiyasının genişləndirilməsi onun fəaliyyətinin strateji istiqamətidir. Dünyanın aparıcı agentliklərinin zəngin təcrübəsinin öyrənilməsi və yeni əlaqələrin qurulması daim diqqət mərkəzindədir. Hazırda Anadolu agentliyi (Türkiyə), ITTAR-TASS (Rusiya), Sinxua (Çin), Ukrinform (Ukrayna),ANSA (İtaliya), BTA (Bolqarıstan),MENA (Misir), TANYUQ (Serbiya), MTI (Macarıstan), İRNA (İran), Aqerpress (Rumıniya), Antara (İndoneziya), BELTA (Belarus), ATA (Albaniya), "Petra" (İordaniya), KUNA (Küveyt), Kazinform (Qazaxıstan),
"Kabar" (QırğıZıstan), "Xovar” (Tacikistan), Yonhap (Koreya Respublikası), KYODO (Yaponiya) agentlikləri ilə qarşılıqlı əməkdaşlıq haqqında ikitərəfli sazişlər bağlanmışdır. Həmin sazişlər agentliyin beynəlxalq miqyasda nüfuzunun getdikcə artmasinın daha bir tosdiqidir (Aslanov,A.,Musayev,V.,@İsmayılov,D.,2008, 44-45). Hazırda AZORTAC 90-dan çox xəbər agentliyi ilə informasiya mübadiləsi aparı, OANA, EANA, BSANNA, TKA, ANIA, Asia Pulse kimi dünyanın ən mötəbər xəbər agentlikləri təşkilatına üzv olmuşdur. Belə ikitərəfli və çoxtərəfli əməkdaşlıq AZəRTAC -a həmin qurumların informasiya resurslarından istifadə etməklə Azərbaycan haqqinda həqiqətləri beynəlxalq aləmdə daha geniş coğrafiyada yaymağa, eyni zamanda, Azərbaycan oxucusunu dünyadakı yeniliklərlə, ən mühüm hadisələrlə təmin etməyə imkan verir (Aslanov, 2010, 182).

2016-c1 il AZӘRTAC-ın həyatında yeni uğurları qaldı: agentlik eyni vaxtda iki böyük tədbirə - Dünya Xəbər Agentliklərinin V Konqresinə və Asiya və Sakit Okean Ölkələri İnformasiya Agentlikləri Təşkilatının (OANA) XVI Baş Assambleyasına ev sahibliyi etdi. Heydər Oliyev Fondunun dəstəyi ilə təşkil olunan mötəbər beynəlxalq tədbirlərdə 80 ölkədən 130 xəbər agentliyinin 200-dək rəhbəri və təmsilçisi, media üzrə beynəlxalq ekspertlər, BMTUNESCO-nun rəsmi nümayəndəsi, həmçinin regional media qurumlarının əməkdaşları iştirak etdilər. Prezident İlham Oliyevin bu tədbirlərin birgə açılış mərasimindəki nitqi, konqres iştirakçıları ilə görüşü böyük maraq doğurdu. Dünyanın informasiya siyasətini müəyyənləşdirən peşəkar xəbər agentliklərinin təmsilçiləri Azərbaycan dövlətinin rəhbərinin məntiqini, cəmiyyət-dövlət-media münasibətlərinə kreativ yanaşmasını yüksək qiymətləndirdilər. Qeyd edək ki, 2007-ci il dekabrın 12-də bu OANA-nın Baş Assambleyasının İndoneziyanın paytaxtı Cakartada keçirilmiş iclasında AzərTAc bu qurumun rəhbər orqanına - İcraiyyə Komitəsinə üzv seçilmişdir. Anadolu Agentliyi İdarə Heyətinin keçmiş sədri və baş direktoru Hilmi Bengi OANA İcraiyyə Komitəsinin 30-cu iclasında çıxışında bu mühüm hadisəni qiymətləndirərək demişdir: "Bu, dünya media məkanında öz mövqelərini möhkəmlədən AzərTAc üçün çox mühüm hadisə idi" (Hilmi, 2008, 62-63).

Azərbaycan Respublikasının Prezidenti İlham Oliyevin OANA İcraiyyə Komitəsinin 30-cu iclasının iştirakçılarına ünvanladığı məktubda deyilirdi: “İnformasiya agentliklərini birləşdirən böyük regional təşkilatların və nüfuzlu xəbər agentliklərinin rəhbər şəxslərinin iştirakı ilə belə bir tədbirin Bakı şəhərində keçirilməsi beynəlxalq aləmə inteqrasiya yolu seçmiş və dünya informasiya məkanına daxil olmuş müstəqil ölkəmizin ictimai həyatında mühüm hadisədir (Azərbaycan Respublikasının Prezidenti İlham Oliyevin Asiya vo Sakit Okean Ölkələri Xəbər Agentlikləri Təşkilatı (OANA) İcraiyyə Komitəsinin 30-cu iclasının iştirakçılarına məktubu. (“Azərbaycan” qəz., 2008, 3 sentyabr).

Beynəlxalq media qurumlarının Bakıda keçirilən tədbirlərini dünyanın 150-dən çox xəbər agentliyi işıqlandırdı. Bu möhtəşəm tədbirdən sonra həm Dünya Xəbər Agentlikləri Konqresinə, həm də OANA-ya sədrlik AZəRTAC-a keçdi. Agentlik 2019-cu ilədək hər iki quruma rəhbərlik etməkdədir.

\section{Nəticə: Müasir Azərbaycanın uğurlarını daha geniş coğrafiyada operativ işıqlandıran agentlik}


Azərbaycan Respublikasının varisi olan AXC dövründə yaradılmış qurumlar bu gün daha mürəşəkkil şəkildə ənənələri yaşatmaqda və cəmiyyətə töhvələrini verməkdədir. Respublikanın baş xəbər agentliyi olan AZӘRTAC-1n Cümhuriyyət dövründə yaradılan və bu dövrdən başlayan inkişaf yolu da tariximizin şərəfli bir hissəsidir. İstər sovetlər dövründə, istərsə də ikinci müstəqillik illərində agentliyin inkişafi, maddi-texniki bazasının möhkəmləndirilməsi və ən nəhayət dünya miqyasına çıxmasının bütün təminatları Ulu öndərimiz Heydər Oliyevin adı ilə bağlıdır. Bu möhtəşəm tendensiya bu gün də uğurla davam etdirilməkdə, dünya informasiya məkanında AZORTAC-in əhəmiyyətli yerini möhkəmlətməkdədir. Bu önəm mətbuat tədqiqatçılarınin da diqqət mərkəzində olmuş və layiqincə dəyərləndirilmişdir: "Beynəlxalq informasiya məkanında Azərbaycanın mövqeyinin möhkəmlənməsində, ölkəmiz haqqında həqiqətlərin dünya media səhnəsinə çıxarılmasında, xalqımızın üzləşdiyi problemlər haqqında beynəlxalq ictimaiyyətə obyektiv, dolğun və düzgün məlumatların çatdırılmasında Azərbaycan Demokratik Respublikasının yadigarı olan Azərbaycan Dövlət Teleqraf Agentliyi AzərTAc-1n böyük rolu var" (Məmmədov, 2013, 119).

Azərbaycan Xalq Cümhuriyyəti dövründə yaradılan və o mürəkkəb zaman kəsiyində Azərbaycan reallıqlarının, ölkənin ictimai-siyasi həyatı, hərbi quruculuq işləri, iqtisadi uğurlar, hökümətin və parlamentin fəaliyyəti haqqında məlumatların yayılmasında əvəzsiz xidmətləri olan milli agentlik bu gün də fəaliyyətini uğurla davam etdirməkdədir. Hələ o vaxtlar qarşıya qoyulan və ölkənin içtimai-siyasi həyatı ilə bağlı olan önəmli məsələlərin dünya içtimaiyyətinə çatdırılması bu gün də aktuallığını saxlayır və AZORTAC regionda 7 dildə informasiya və 5 dildə videoxəbər yayan yeganə agentlikdir. Ölkə həyatının bütün sahələrində baş verən hadisə və yenilikləri, o cümlədən Azərbaycanın uğurlarını daha geniş coğrafiyada operativ işıqlandıran agentliyin xəbərləri hazırda dünyanın 100-dən çox ölkəsinə yayılır. AZӘRTAC buna həm xaricdə fəaliyyət göstərən müxbir məntəqələri, həm də təmsil olunduğu beynəlxalq media qurumları, əməkdaşlıq etdiyi xarici informasiya agentlikləri vasitəsi ilə nail olmaqdadır. Mətbuat tədqiqatçısı Şamil Vəliyev onu "Azərbaycan informasiya mühitinin lideri” və “... yalnız tarixin və bugünün deyil, həm də azad və demokratik Azərbaycanın daha xoşbəxt gələcəyinə yönələn yolun” (Vəliyev, 2011) işıqtutanı adlandirır.

Müasir Azərbaycanın siyasi, iqtisadi və sosial həyatının bütün sahələrində baş verən hadisə və yenilikləri, o cümlədən Azərbaycanın uğurlarını daha geniş coğrafiyada operativ işıqlandıran agentliyin xəbərləri hazırda dünyanın 100-dən çox ölkəsinə yayılır. AZӘRTAC buna həm xaricdə fəaliyyət göstərən müxbir məntəqələri, həm də təmsil olunduğu beynəlxalq media qurumları, əməkdaşlıq etdiyi xarici informasiya agentlikləri vasitəsi ilə nail olmaqdadır. Bu reallıqları dəyərləndirən professor Həmid Vəliyev inamla bildirir ki, "Müstəqil Azərbaycanımızın 1 nömrəli informasiya agentliyinin Avropada, Asiyada, Afrikada, Amerikada tanınması, şöhrət qazanması, onun informasiyalarından müxtəlif ölkələrdə istifadə edilməsi, Azərbaycan həqiqətlərinin dünyaya çatdırılması bu media qurumunun gözəl perspektivlərə malik olduğunu göstərir" (Voliyev, 2013).

Sovet rejimi dövründə yaşadığı çətinliklər, məhdudiyyət və sıxıntılar agentliyin həyatında təsirsiz qalmamışdır. Hətta bu dövrün böyük bir mərhələsində milli kadırların buradakı yer tutmasına və onların irəli çəkilməsinə imkan verilmədiyindən fəaliyyətləri yox dərəcəsində olmuş, qeyri millətlərdən olan kadrların işə cəlb edilməsi və onların fəaliyyətlərinə önəm verilməsi agentliyin və idealoji fəaliyyətin ümdə hissəsi olmuşdur. Amma bütün bu "üzdə olmayan qadağalara" baxmayaraq, AZӘRTAC Azərbaycan tarixinin təxminən bir əsrlik salnaməsini yarada bilmişdir. "Dövlət müstəqilliyimizin bərpasından sonrakı illər isə onun inkişafının tam fərqli dövrüdür: agentlik ən müasir informasiya texnologiyaları ilə təchiz olunub, mobil, peşəkar yaradıcı komandaya və texniki heyətə malikdir. Azərbaycanın dinamik inkişafı və artan nüfuzu fonunda AZӘRTAC da cəsarətlə dünya arenasına çıxır, beynəlxalq informasiya məkanında mövqeyini getdikcə möhkəmləndirir. Vaxtilə səsi Azərbaycandan kənara çıxmayan AZӘRTAC bu gün dünyanın ən mötəbər iki media qurumuna - Dünya Xəbər Agentlikləri Konqresinə və Asiya və Sakit Okean Ölkələri Xəbər Agentlikləri Təşkilatına (OANA) rəhbərlik edir (AZORTAC, 2018)

\section{Kaynakça}

ARDA. Azərbaycan Respublikası Dövlət Arxivi, f.51, siy.1, sax., vah. 33, var.104

Aslanov, A. (2005). Heydər Oliyev və AzərTAc. Bakl: Nurlan,2005,178s.

Aslanov, A., Musayev, V., İsmayılov, D. (2008). AzərTAcdan AzərTAc-a: mürəkkəb və şərəfli yol. Bakı: Şərq-Qərb, , səh. 184.

Aslanov, A.. (2010). AZӘRTAC-ın xarici əlaqələrinin yaranması vo inkişafı (1991-2010-cu illor). Bakl Universitetinin Xabarlari, Humanitar elmlar seriyasl, №3,180-184

Aslanov, A.. (2011). Müasir dünyanın informasiya şəbəkəsində AzərTAcın yeri: təşəkkül tarixi və inkişaf mərhələləri, 2011, 232 səh.

Azərbaycan Xalq Cümhuriyyəti Ensiklopediyası: İki cilddə, I cild, Bakı, Lider Naşriyyatı, 2004, 440 s.

AzərTAc-1n xəbəri. (1920). “Azərbaycan” qəzeti, 2 mart

AzərTAc-1n daxili xəbərləri. (1920). “Azərbaycan” qəzeti, 3 mart

AZӘRTAC. (2018). Azərbaycanın 98 illik tarixinin günbəgün yazılan salnaməsi. 1 mart,https://azertag.az/xeber/

AZARTAC_Azerbaycanin_98_illik_tarixinin_gunbegun_yaz ilan_salnamesi_VIDEO-1141108

Gürcüstana yardım, (1920), “Azərbaycan” qazeti, 9 mart

Azərbaycan Respublikasının Prezidenti İlham Oliyevin Asiya və Sakit Okean Ölkələri Xəbər Agentlikləri Təşkilatı (OANA) İcraiyyə Komitəsinin 30-cu iclasının iştirakçılarına məktubu, (2008), “Azərbaycan” qəzeti.,3 sentyabr

Enserov, V. (2009). Azerilerin 90 y1llık sesi AZERTAC. Bizim Gazete. Turkiye, 26 Ekim.

Ohmədov, N. (2018a). "Cümhuriyyətin AzərTAc yadigarı: yaranma zərurəti və keçdiyi yol” 525-ci qazet,7 mart 
Ohmədov, N., (2018b), Cümhuriyyət dövrü milli mətbuatimiz və dövlətçilik. Ipak yolu, No.1, 2018, sah.36-40

Feyziyev C. (2011). AXC xalqımızın milli oyanışının məntiqi yekunu idi, Xalq qazeti,27 may.

Hilmi. B. (2009). Qloballaşan dünyada informasiya hamı üçün. Bakl: Şərq-Qərb, , 479 s.

Məmmədov, S. (2013). "Azərbaycanın beynəlxalq mediakommunikasiya əlaqələrinin inkişafi”. Tarix və onun problemlari, № 3, s.117-121

Şərifov, A. (2008). Bu bizim tariximizdir.AzərTAc-dan AzərTAc-a mürəkkəb və şərəfli yol.Bakl, Şərq-Qərb, s.1013.

Vəliyev, Ş. (2011),“AzərTAc-ın tarixi və müasir həqiqət axtarışı”. “Azərbaycan” qazeti”, 2 noyabr

Vəliyev, H. (2013). "Dövlət siyasətinin informasiya təminatı", 525-ci qazet, 2 may 
